AL IBTIDA: JURNAL PENDIDIKAN GURU MI (2021) Vol 8 (1) : 93-103

DOI: http://dx.doi.org/ 10.24235/al.ibtida.snj.v8i1.7459

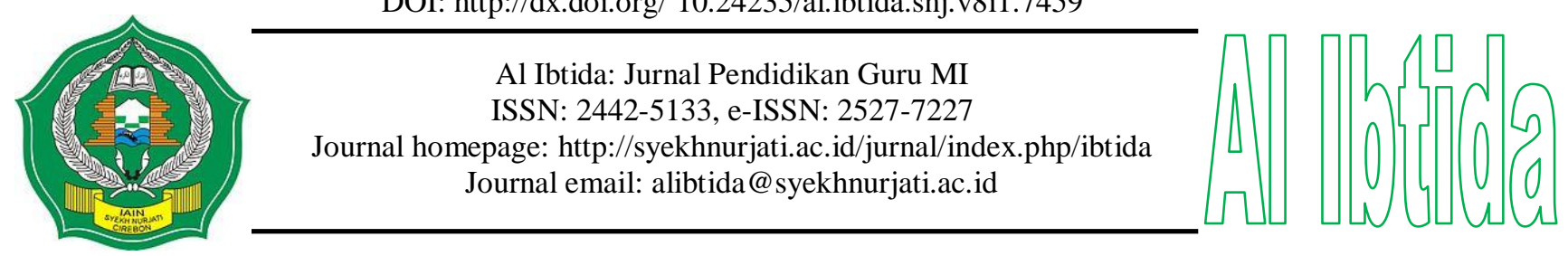

\title{
A Children's Music Therapy to Enhance the Self-Esteem of Children with Attention Deficit Hyperactivity Disorder (ADHD) in Elementary School
}

\author{
Abdul Sholeh* \\ *Department of Elementary School Teacher Education, Faculty of Education and Teacher Training, \\ Universitas Nahdlatul Ulama Cirebon, Indonesia \\ Email: abdulsholeh032@gmail.com \\ Asep Supena** \\ **Basic Education Department, Graduate School Program, \\ Universitas Negeri Jakarta, Indonesia \\ Email: asupena@unj.ac.id
}

Received: February $14^{\text {th }}, 2021$. Accepted: June 12 $2^{\text {th }}, 2021$. Published: June $27^{\text {th }}, 2021$.

\begin{abstract}
Elementary school students with Attention Deficit Hyperactivity Disorder (ADHD) possessed low self-eesteem that impacted on their academic failure. This study aims to describe the use of a children's music therapy to enhance the self-esteem of ADHD students. Using a qualitative case study to garner the data from ADHD students, this study included pre-field stages, activities during the field, and post empirical stages. Data were analyzed using observations and interviews. The results of the research show that the children's music therapy can be used as an alternative in developing the self-esteem of ADHD children in an elementary school. It can be seen from their development of several aspects including ability (competence), meaning (significance), goodness (virtue), and strength (power). Therefore, elementary school teachers are advised to use the music therapy to enhance the self-esteem of ADHD children. As a medium of healing and to overcome anxiety, such therapy could allow students to gain self-acceptance, get acceptance by others, be able to complete tasks, be able to make decisions, be able to control themselves, and have better selfawareness.
\end{abstract}

Keywords: a children's music therapy, self-esteem, attention deficit hyperactivity disorder. 


\begin{abstract}
Abstrak
Siswa sekolah dasar dengan Attention Deficit Hyperactivity Disorder (ADHD) memiliki harga diri yang rendah yang berdampak pada kegagalan akademik mereka. Penelitian ini bertujuan untuk mendeskripsikan penggunaan terapi musik anak untuk meningkatkan harga diri siswa ADHD. Menggunakan studi kasus kualitatif untuk mengumpulkan data dari siswa ADHD, penelitian ini meliputi tahap pra-lapangan, kegiatan selama lapangan, dan pasca empiris tahap. Teknik analisis data menggunakan observasi dan wawancara. Hasil penelitian menunjukkan bahwa terapi musik anak dapat digunakan sebagai salah satu alternatif dalam mengembangkan harga diri anak ADHD di sekolah dasar. Hal ini dapat dilihat dari perkembangan mereka dari beberapa aspek antara lain kemampuan (competence), makna (significance), kebaikan (virtue), dan kekuatan (power). Oleh karena itu, guru sekolah dasar disarankan untuk menggunakan terapi musik untuk meningkatkan harga diri anak ADHD. Sebagai media penyembuhan dan mengatasi kecemasan, terapi tersebut dapat memungkinkan siswa untuk memperoleh penerimaan diri, mendapatkan penerimaan oleh orang lain, mampu menyelesaikan tugas, mampu mengambil keputusan, mampu mengendalikan diri, dan memiliki kesadaran diri yang lebih baik.
\end{abstract}

Kata kunci: terapi musik anak, harga diri, attention deficit hyperactivity disorder.

\title{
INTRODUCTION
}

Since primary education is important for the students' development, students aged 6-12 years should be able to develop cognitive, affirmative, and psychomotor abilities, as well as characters to achieve academic goals. But in reality, there are various problems for students in that age including Attention Deficit Hyperactivity Disorder (ADHD). ADHD is categorized as a disorder of nerve/brain development, indicated by hyperactivity and impulsivity that interfere with the functioning and development of the child's brain (Nielsen, 2017; American Psychiatric Association, 2013). ADHD is one of the most common childhood psychiatric disorders, characterized by the age-inappropriate indimptive, motor hyperactivity and impulsiveness (Gevensleben, et al, 2012; Climie \& Mitchell, 2017). As said by Antshel, Zhang-James, \& Faraone (2013), ADHD is characterized by the development of a degree of indimpacy, impulsivity and/or hyperactivity that remains relative over time, causing damage in some domains of daily life activities. ADHD is a psychiatric developmental disorder due to the brain/nerves/neurologist that has signs of incommission or motoric hyperactivity and impulsiveness.

Factors causing children ADHD include genetic factors, neurobiological factors, and dietary factors, allergies, and lead substances. Genetic factors also play an important role in causing ADHD (Kuntsi \& Stevenson, 2000). ADHD occurs in the family of one-third of family members of ADHD children having the disorder (Farone, 2000). So, if parents have ADHD, children have a $60 \%$ risk of ADHD (Biederman, et al. 1995). An ADHD neurobiologist factor is a direct or indirect factor (Falk et al., 2015). Indirect factors include: 
postnatal coffers, such as birth complications and diseases, environmental poisoning, lead content, language nods, and neurological immatureness. Dietary factors, allergies, and lead substances, aditif fods, preservatives, artificial dyes, and flavors are major causes of ADHD. In addition, additives in food cause the child hyperactivity and intentive. Low-level lead substances found in dust, oil, and paint in areas where gasoline and disposable paint are directly disposed of can be associated with ADHD symptoms (Leung, et.al, 1994). Behavioral classification of ADHD children include: overactivity, hipertactivity, and hyperkinetic syndrome. Overactivity is the behavior of children who do not want to be silent caused by energy excess. Hyperactivity is a pattern of overactive behavior that tends to be erratic (out of place) and hyperkinetic, such as having speech difficulty, often moving hands or feet or circling in the seat, often leaving the seat when in class, always running there or like to climb, often facing problems to play, talking a lot and often moving.

In Humphreys' et al. (2012) research, it is stated that out of 203 boys and girls aged 6 to 9 years, the category of ADHD in children is higher than those in adolescents. As said by Leung, et al. (1994), there are 25\% of ADHD children with symptoms characterized by anxiety or phobia disorders, certain learning disabilities at home and at school. The results of research by Nurfitriana et al. (2019) reveal that $15.8 \%$ of children aged 3-18 years old have ADHD. In addition, the results of the interviews on October 4, 2020 with grade IV elementary school teachers in Kota Cirebon reveal that the number of students with ADHD amounted to 5 students or $22.72 \%$.

ADHD has a negative impact on daily life functions such as impaired academic, occupational, and social functions (Thorell et al., 2019). Children with ADHD experienced academic failure, peer rejection, loss of self-esteem, loss of motivation, and helplessness of learning, unfocused, defiant, destructive, tireless, aimlessly clear, and nosy (Leung, et.al, 1994). They tend to act carelessly, irritable, forget school lessons and homework, have difficulty doing chores at school and at home, have difficulty in listening, have difficulty in carrying out some commands, daydreaming, have a lack of patience, often make noise, and have difficulty in speaking (Marliana et al. 2017). Children with ADHD are susceptible to academic failure; they often possess low self-esteem and have difficulty in completing tasks.

Self-esteem is one of the most important parts of one's personality in everyday life. Daniel \& Reynolds (2011) defines self-esteem as a personal assessment of worthiness demonstrated by an individual's attitude toward himself or herself. The judgment a person makes with regard to himself is shown through a disagreement or disagreement. According to Coopersmith, self-esteem is defined as an evaluation made and habits in looking at him, 
especially regarding the attitude of accepting and rejecting. Coopersmith further revealed that there are four basics of self-esteem, namely competence, significance, virtue, and strength (Sabibah, 2013). Self-esteem relates to an image or positive judgment, a person to himself (Santrock, 2007). Self-esteem is a very important concern because it relates to a number of life factors; one of which is the success of students in the classroom (Young \& Hoffmann, 2004). Self-esteem can be defined as an individual's assessment of his or her ability to learn and feasibility for peers and teachers; it is demonstrated through his or her own attitude in learning. Lawrence (2006) states that students with high self-esteem tend to be confident in the social situations faced and confident in handling the tasks given by teachers, maintaining their natural curiosity in learning and having passion and enthusiasm when facing new challenges. On the contrary, students with low self-esteem avoid situations that have a potential to make them feel ashamed in front of others. Students with low self-esteem tend to prefer to be punished or perhaps seen as a "whiz" by their peers rather than look stupid. The treatment of ADHD students with low self-esteem generally uses pharmacological therapy, but the single therapy is not recommended because in the long run it can lead to addiction even drug dependence until adulthood (Martin et.al, 2008). Therefore, to overcome the problem of ADHD students with low self-esteem, appropriate and effective approaches are needed, including the implementation of children's music therapy approach.

A music therapy for children is one way of healing that can be applied to ADHD children, through the medium of music treatment strategies for ADHD children, that is non verbal (Jackson, 2003). The main purpose of music therapy is for behavioral changes, followed by psychosocial and cognitive purposes. Musical therapy approach is beneficial for maintenance, relaxation, reflection, expressing emotions, learning (Gao, et al., 2013). In addition, based on the results of Wheeler's research (2016), the approach of music therapy can increase the sense of purpose in life and self-awareness. Inherently, a non-threatening and fun medium, music therapy has the potential to provide a safe and nurturing environment for traumatized clients (Day, Baker, \& Darlington, 2009). Felsenstein (2013) suggests music therapists to overcome children's difficulties in verbal processing, provide a means of nonverbal self-expression, emotional communication and social interaction, which can empower and heal children who have difficulty with verbal expression. Kim (2015) stated that music therapy can support children to interact with freedom and joy through music games and foster relationships with others. This subjective and inter-subjective moment in this creative music experience can create conditions for the child to explore different ways to be, interact and communicate (Thompson \& Elefant, 2019). Music therapists should be built with a choice 
given to the genre of songs, harmonic progressions, melodies, rhythms, and instrumentation (Pasiali, 2012). Music is a universal medium of speaking in various forms; music can also voice the hearts of its listeners, communicate and evoke a series of emotions, for example, in conveying feelings towards a person or something (Dharmasasmitha \& Widiasavitri, 2017). Music is the work of human beings that can not be separated in life (Shaleha, 2019). Music has benefits in the development of elementary school students' learning, such as improving learning outcomes, self-esteem, emotional, intelligence, memory, concentration, and calming hyperactive students. Children and music have a strong connection; music is useful to improve the learning development of children. Music was used as acatalyst to stimulate emotions and usher individuals into a state of relaxation; until later the Greeks in the fifth century BC used certain types of music to cope with people who had problems (Grocke \&Wigram, 2007). Music applications can be found in a variety of settings; one of which is research in the field of education that shows that music can improve a person's IQ score and can improve the spatial performance of individuals (Schellenberg, 2004). Hallam (2010) also explained that in childhood, music is related to language acquisition. The results of research show that music therapy can lower anxiety, stress, and depression and is effective in improving the quality of life (Grocke, Bloch, \& Castle, 2009). Another study conducted by Labbé, et. al (2007) explained that listening to music after exposure to stressors significantly lowers negative emotions. The purpose of this study is to describe the implementation of children's music therapy approach to increase the self-esteem stimulus of ADHD children in an elementary school.

\section{METHODS}

A qualitative case study was empolyed in this research. Spradley (2016) stated that in a qualitative research, there is a social situation that consists of three elements namely place (place), actors (actors) and activities (Activity). The design of the case study research covers three other stages including: 1. Pre-field stage, 2. Field stage, and 3. Post-field Stage (Mudjia, 2017). Among 22 four graders of an elementary school in Cirebon, 5 students (22,72 $\%$ ) diagnosed with ADHD were involved in this study. Data collection instruments and techniques used were observations and interviews, literature studies, triangulation, and questionnaires to obtain data or facts based on ADHD characterization of students' activities in school; the data analysis stage include description, reduction, and selection (Sugiyono. 2007).

Observations were made directly before implementing the approach of music therapy and during and after the approach of children's music therapy, to obtain information about the 
self-esteem of ADHD children in an elementary school through videos, photos, and observation sheets. Interviews were done to know the development of self-esteem through the child's music therapy approach through the interview sheet. The validity of the instrument is determined by the assessment of an expert of children with special needs. The activities carried out a include 1. Identifying ADHD children with low self-esteem, 2. Determining the cases of ADHD in children 3. Giving treatment using children's music therapy, 4. Describing and analyzing cases 5. Making description after the treatment.

\section{RESULTS AND DISCUSSION}

The data of the research were obtained through data collection techniques, namely observations, interviews, literature studies, triangulation, and questionnaires based on the characteristics of ADHD students as seen from their activities in the school environment or at home. The approach of children's music therapy is done by playing children's music that they like such as Indonesian songs such as 'bangun tidur ku terus mandi', 'cicak-cicak di dinding', 'balonku', or 'pelangi-pelangi'.

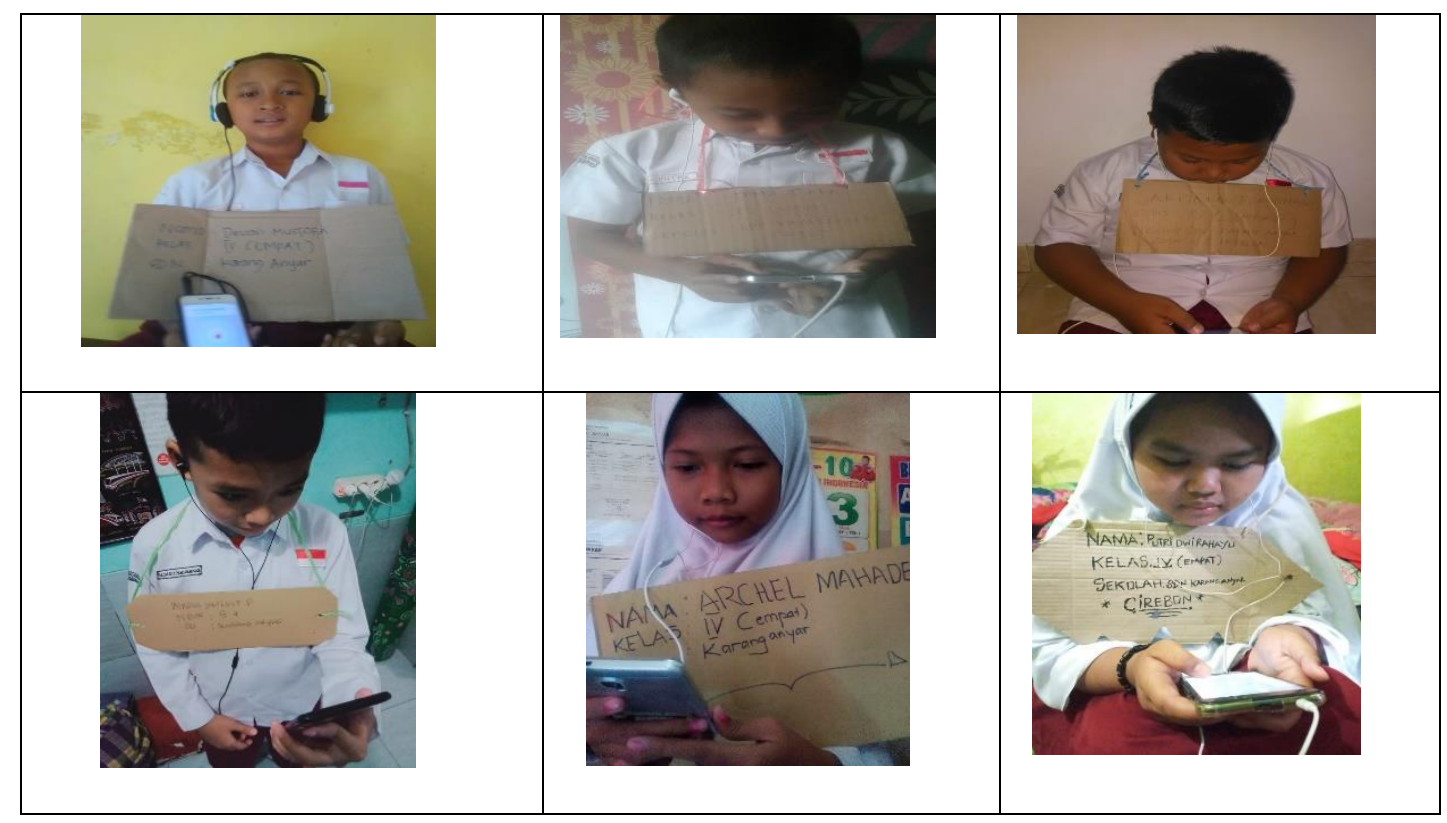

Figure 1. A Photo of elementary school students in Cirebon listening to children's music

For strengthening and simplifying the data that has been obtained, coding was done to know the development of self-esteem through the approach of children's music therapy, as shown in the table 1. 
Table 1. Basic Elements of Self-Aesthetics in ADHD Children in an Elementary School in Cirebon

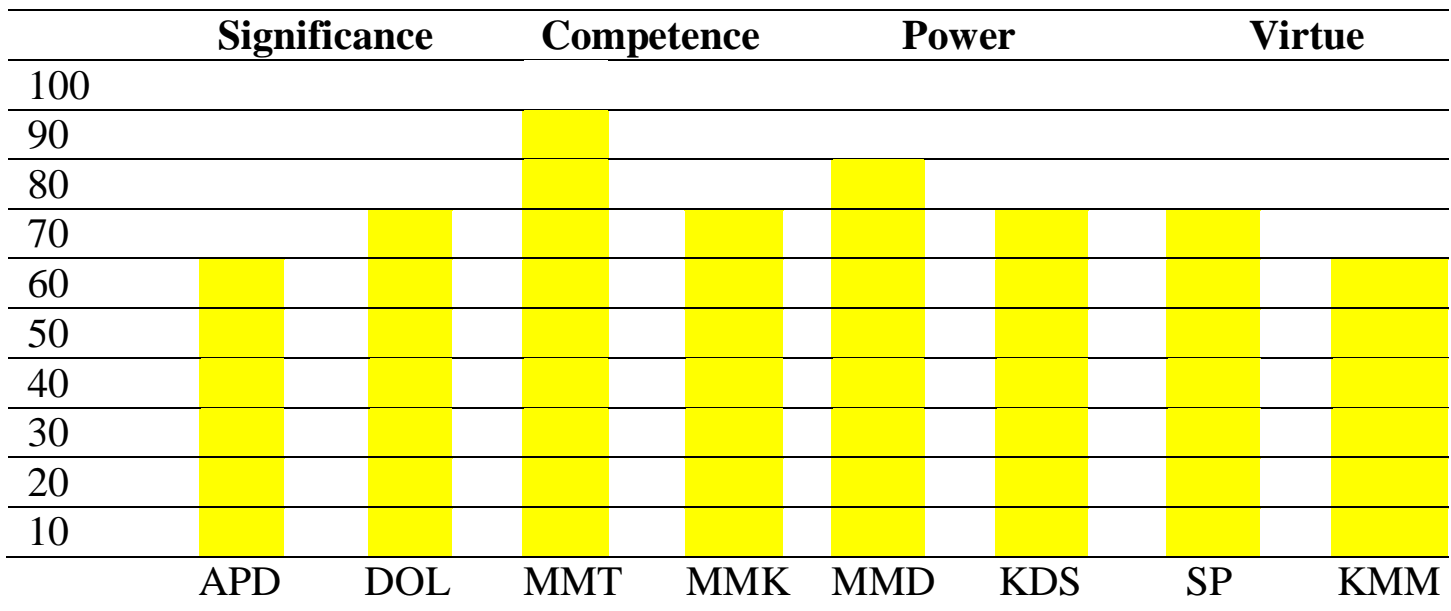

Information:

1. APD = Self-acceptance

2. DOL = Accepted by others

3. $\mathrm{MMT}=$ Able to complete tasks

4. $\mathrm{MMK}=$ Able to make decisions

5. $\mathrm{MMD}=$ Able to control yourself

6. KDS = Self-awareness

7. $\mathrm{SP}=$ Positive attitudes

8. $\mathrm{KMM}=$ Seriousness in solving problems

Based on the data in the table, regarding the self-esteem of ADHD children, the table shows that students diagnosed with ADHD at one of state elementary schools in Cirebon City experienced self-acceptance and accepted by others after being given a musical therapy treatment. The self-esteem of elementary school students diagnosed with ADHD at first low; after being given stimulus through the approach of music therapy children, students are calmer in learning, more focused in listening to what is conveyed by the teacher, felt accepted by others. This shows that through the approach of music therapy, children experience a change in behavior, they become calmer in learning. This is in agreement with Jackson (2003), music therapy is non-verbally conducted with the main purpose for behavioral changes, followed by psychosocial and cognitive purposes.

In the aspect of competence, with two indicators including completing tasks and being able to make decisions, through the approach of children's music therapy, ADHD children are experiencing better development than before. After being given a child music therapy approach, ADHD students are able to complete tasks, partly through communication with teachers and among students. In addition, with a child's music therapy approach, ADHD students with low self-esteem become more able to make decisions in doing tasks from teachers, among others, because of the internal support on calmer conditions and language 
familiarity with peers through singing together. This is similar to Hallam (2010) who explained that as a child, music is related to language acquisition.

In the aspect of power (strength), with two criteria including being able to control yourself and self-awareness, after being given a music therapy through children's music media, the ADHD children immediately become silent, listen to songs and are able to listen to what is conveyed by teachers; they could also understand the meaning of children's songs and give smiles. This agrees with research by Chang, Chen, \&Cuang (2008) that shows that a music therapy can lower anxiety, stress, and depression.

In the aspect of virtue (goodness), with two indicators including positive attitudes and seriousness of solving problems, after being given a music therapy, through listening to child's music, the ADHD children immediately listen and could listen to it well. This shows that they develop a positive attitude that leads them to be able to solve learning problems. Listening to children's music can foster a sense of beauty in life, a high sensitivity to feelings, and then the children will be able to make decisions steadily and form a formidable character. It is agreed that certain types of music could address people who have problems (Grocke \&Wigram, 2007)

\section{CONCLUSION}

Based on the above exposure, it can be concluded that the implementation of children's music therapy approach can stimulate the self-esteem of elementary school students diagnosed with ADHD who have academic failure, carelessness, irritability, forget school lessons and homework, and have difficulty doing the tasks. Children's music therapy approach is a medium in healing and developing self-esteem in in several aspects including ability (competence), meaning (significance), goodness (virtue), and strength. It is characterized by several aspects including the presence of self-acceptance, feeling accepted by others, being able to complete tasks, being able to make decisions, being able to control themselves, being aware of one self, having positive attitudes, and being serious in problem solving.

\section{REFERENCES}

American Psychiatric Association. (2013). Diagnostic and statistical manual of mental disorders (DSM-5®). American Psychiatric Pub.

Antshel, K. M., Zhang-James, Y., \& Faraone, S. V. (2013). The comorbidity of ADHD and autism spectrum disorder. Expert review of neurotherapeutics, 13(10), 1117-1128. 
Biederman, J., Wilens, T., Mick, E., Milberger, S., Spencer, T. J., \& Faraone, S. V. (1995). Psychoactive substance use disorders in adults with attention deficit hyperactivity disorder (ADHD): effects of ADHD and psychiatric comorbidity. American Journal of Psychiatry, 152(11), 1652-1658.

Chang, M. Y., Chen, C. H., \& Huang, K. F. (2008). Effects of music therapy on psychological health of women during pregnancy. Journal of clinical nursing, 17(19), 2580-2587.

Climie, E. A., \& Mitchell, K. (2017). Parent-child relationship and behavior problems in children with ADHD. International Journal of Developmental Disabilities, 63(1), 2735 .

Daniel, M., \& Reynolds, D. (2011). Effective teaching: evidence and practice. Los Angeles: SAGE, 2(4), 25-31.

Day, T., Baker, F., \& Darlington, Y. (2009). Experiences of song writing in a group programme for mothers who had experienced childhood abuse. Nordic Journal of Music Therapy, 18(2), 133-149.

Dharmasasmitha, V., \& Widiasavitri, P. N. (2017). Perbedaan Kecerdasan Emosi Antara Pendengar Musik Hardcore dengan Pendengar Musik Klasik. Jurnal Psikologi Udayana, 4(1), 1-8.

Falk, A. E., Lee, S. S., \& Chorpita, B. F. (2017). Differential association of youth attentiondeficit/hyperactivity disorder and anxiety with delinquency and aggression. Journal of Clinical Child \& Adolescent Psychology, 46(5), 653-660.

Farone, D. W. (2000). When a Child Has Been Murdered: Ways You Can Help the Grieving Parents. Families in Society, 81(6), 638.

Felsenstein, R. (2013). From uprooting to replanting: On post-trauma group music therapy for pre-school children. Nordic Journal of Music Therapy, 22(1), 69-85.

Gao, T., O'Callaghan, C., Magill, L., Lin, S., Zhang, J., Zhang, J., ... \& Shi, X. (2013). A music therapy educator and undergraduate students' perceptions of their music project's relevance for Sichuan earthquake survivors. Nordic Journal of Music Therapy, 22(2), 107-130.

Gevensleben, H., Rothenberger, A., Moll, G. H., \& Heinrich, H. (2012). Neurofeedback in children with ADHD: validation and challenges. Expert review of neurotherapeutics, 12(4), 447-460.

Grahn, J. A., \& Brett, M. (2009). Impairment of beat-based rhythm discrimination in Parkinson's disease. Cortex, 45(1), 54-61.

Grocke, D., \& Wigram, T. (2006). Receptive methods in music therapy: Techniques and clinical applications for music therapy clinicians, educators and students. Jessica Kingsley Publishers.

Grocke, D., Bloch, S., \& Castle, D. (2009). The effect of group music therapy on quality of life for participants living with a severe and enduring mental illness. Journal of music therapy, 46(2), 90-104.

Hallam, S. (2010). The power of music: Its impact on the intellectual, social and personal development of children and young people. International Journal of Music Education, 28(3), p. 269-289. doi: 10.1177/0255761410370658

Humphreys, K. L., Aguirre, V. P., \& Lee, S. S. (2012). Association of anxiety and ODD/CD in children with and without ADHD. Journal of Clinical Child \& Adolescent Psychology, 41(3), 370-377. 
Jackson, N. A. (2003). A Survey of Music Therapy Methods and Their Role in the Treatment of Early Elementary School Children with ADHD, Journal of Music Therapy, 40(4), 302-323, https://doi.org/10.1093/jmt/40.4.302

Kim, J. (2015). Music therapy with children who have been exposed to ongoing child abuse and poverty: A pilot study. Nordic Journal of Music Therapy, 24(1), 27-43.

Kuntsi, J., \& Stevenson, J. (2000). Hyperactivity in children: A focus on genetic research and psychological theories. Clinical Child and Family Psychology Review, 3(1), 1-23.

Labbé, E., Schmidt, N., Babin, J., \& Pharr, M. (2007). Coping with stress: the effectiveness of different types of music. Applied psychophysiology and biofeedback, 32(3), 163-168.

Lawrence, D. (2006). Enhancing self-esteem in the classroom. Pine Forge Press.

Leung, A. K. C., Robson, W. L. M., Fagan, J. E., \& Lim, S. H. (1994). Attention-deficit hyperactivity disorder: Getting control of impulsive behavior. Postgraduate medicine, 95(2), 153-160.

Marliana, M., Eka, N. L. P., \& Maemunah, N. (2017). Pengaruh Terapi Musik Klasik terhadap Tingkat Konsentrasi pada Anak Attention Deficit Hyperactive Disorder (ADHD) di Yayasan Bhakti Luhur Malang. Nursing News: Jurnal Ilmiah Keperawatan, 2(1).

Martin, G. L., Thorsteinsson, J. R., Yu, C. T., Martin, T. L., \& Vause, T. (2008). The Assessment of Basic Learning Abilities Test for predicting learning of persons with intellectual disabilities: A review. Behavior Modification, 32(2), 228-247.

Nielsen, M. (2017). My ADHD and me: Identifying with and distancing from ADHD. Nordic Psychology, 69(1), 33-46.

Nurfitriana, F., Putri, E. R., Sholikhin, G. R., \& Widyatno, A. (2019). Penerapan Terapi Musik dalam Mengatasi Gejala Hiperaktivitas pada Anak ADHD. Prosiding Seminar Nasional Psikologi Pendidikan, Universitas Negeri Malang.

Pasiali, V. (2012). Resilience, music therapy, and human adaptation: nurturing young children and families. Nordic Journal of Music Therapy, 21(1), 36-56.

Rahardjo, M. (2017). Desain Penelitian Studi Kasus. Malang. UIN Maulana Malik Ibrihim

Rusmawati, D., \& Kumala Dewi, E. (2011). Pengaruh Terapi Musik Dan Gerak Terhadap Penurunan Kesulitan Perilaku Siswa Sekolah Dasar Dengan Gangguan ADHD. Jurnal Psikologi Universitas Diponegoro, 9(1), 74

Sabibah. (2013). Pengembangan Program Bimbingan Pribadi Berdasarkan Profil Self Esteem. Bandung Universitas Pendidikan Indonesia

Santrock, J. W. (2007). Child development. New York: McGrow.

Schellenberg, E. G. (2004). Music lessons enhance IQ. Psychological science, 15(8), 511-514.

Shaleha, R. R. A. (2019). Do re mi: Psikologi, musik, dan budaya. Buletin Psikologi, 27(1), 4351. DOI: 10.22146/buletinpsikologi.37152

Shaleha, R. R. A. (2019). Do re mi: Psikologi, musik, dan budaya. Buletin Psikologi, 27(1), 4351.

Spradley, J. P. (2016). Participant observation. Waveland Press.

Thompson, G. A., \& Elefant, C. (2019). "But I want to talk to you!" Perspectives on music therapy practice with highly verbal children on the autism spectrum. Nordic Journal of Music Therapy, 28(4), 347-359. 
Thorell, L. B., Holst, Y., \& Sjöwall, D. (2019). Quality of life in older adults with ADHD: links to ADHD symptom levels and executive functioning deficits. Nordic journal of psychiatry, 73(7), 409-416.

Wheeler, B.L. (2016). Music Therapy Research: An Overview. Counseling Psychology, Clinical Psychology. Oxford University Press, 3-35.

Young, E. L., \& Hoffmann, L. L. (2004). Self-esteem in children: strategies for parents and educators. National Association of School Psychologists, 4340, 657-0270. 